\title{
Concentrations of Magnesium, Calcium and Potassium in Drinking Water; A Comparison between Tap Water and Bore Water
}

\author{
Michelle Ling Wang Jing ${ }^{1}$, Siti Marwanis Anua ${ }^{1 *}$, Nurzafirah Mazlan ${ }^{2}$ \\ ${ }^{1}$ Environmental and Occupational Health Programme, School of Health Sciences, Health Campus, Universiti Sains \\ Malaysia, 16150 Kubang Kerian, Kelantan, Malaysia. \\ ${ }^{2}$ Department of Diagnostic and Allied Health Sciences, Faculty of Health and Life Sciences, Management and \\ Science University, University Drive, Seksyen 13, 40100 Shah Alam, Selangor, Malaysia. \\ *Corresponding author: smarwanis@usm.my
}

\section{Article History}

Received: March 06, 2019 Received in revised form: May 21, $2019 \quad$ Accepted: May 23, $2019 \quad$ Published Online: June 24, 2019

\begin{abstract}
Minerals content in drinking water are essential for human health. Hence, this cross sectional study aims to determine the concentration of minerals in tap water and bore water consumed among staffs and students of School of Health Sciences, Universiti Sains Malaysia Health Campus. Utilising convenience sampling method, 32 respondents were recruited into this study who agreed for home visit and completed the questionnaires. Based on availability of water samples at home (raw, boiled and filtered), 22 tap water and 10 bore water were collected into $200 \mathrm{ml}$ sampling bottle, in triplicate. Concentration of minerals (magnesium, calcium and potassium) in water samples were analysed using Flame Atomic Absorption Spectrometry (FAAS). There was higher concentration of magnesium, calcium and potassium in tap water compared to bore water but the difference was statistically significance for calcium only $(\mathrm{p}=0.007)$. No significant differences were found in all minerals for both tap water and bore water after filtration or boiling. Concentration of minerals from filtered water samples was found to be higher in galvanised steel pipes compared to polyvinyl chloride. In conclusion, water samples provided by respondents were safe for drinking and cooking as the mineral contents for consumption are below the maximum value of Drinking Water Quality Standard.
\end{abstract}

Keywords: Tap water; bore water; magnesium; calcium; potassium

\subsection{INTRODUCTION}

Water is an essential component for living things which includes human beings, animals and plants. Safe and readily available water is important for drinking, food preparation and cleaning purposes [1]. Bore water is groundwater which can be accessed via drilling a borehole into the underground water storage [2]. The underground water storage can be known as aquifers. An electric or gasoline-powered pump is used to pump the underground water to the surface so that the water can be used. The underground water is transported from underground to surface by using pipes. The source of water for tap water is normally from either surface water or groundwater [3]. Groundwater is a good source of water supply as it is less polluted and when the water flows through the soil, the minerals from the soil will be transported into the groundwater [4]. The water from either surface water or groundwater is treated through several processes; such as aeration, coagulation and clotting, deposition, filtration, chlorination and $\mathrm{pH}$ adjustment before the treated water is send to the water storage tank. Then, the water in the water storage tank is transported via pipes and released from tap. Human beings are required to drink about two litres of water per day to obtain the necessary minerals that is important to human health. Several minerals that can be obtained from water are potassium, sodium, calcium and magnesium [5].

Potassium and sodium are important electrolytes for cellular homeostasis maintenance such as osmotic pressure and water 
distribution in body fluid compartments. These two ions are also crucial for renal regulation of acid-base balance to substitute hydrogen ions in renal tubule. Sodium-potassium flux can be found in nerve cells for generation of electrical potential to aid the conduction of nerve impulses. Eventually, the muscle contractions and heartbeat regulations are generated from the conduction of nerve impulses. Calcium and magnesium are important for bone formation and cardiovascular system. Calcium is an essential element for nerve impulses transmission and blood clotting [6]. The Recommended Dietary Allowance (RDA) of potassium for adults is $4700 \mathrm{mg}$ per day while sodium maximum daily intake is $2300 \mathrm{mg}$ per day [7]. The RDA for magnesium is 400 to 420 $\mathrm{mg}$ per day for males and 310 to $320 \mathrm{mg}$ per day for females [8] while for calcium is $1000 \mathrm{mg}$ per day for adults [9].

The major elements dissolved in groundwater such as magnesium and potassium with concentration of 1 to $10 \mathrm{mg} / \mathrm{L}$ is probably essential for human health [10]. Meanwhile, dissolved sodium and calcium concentration which is probably essential for human health is ranging from 10 to $100 \mathrm{mg} / \mathrm{L}$. A previous study conducted in determining potassium and calcium level in bore water samples which were collected from five different villages in Gua Musang, Jeli and Tanah Merah were ranged 227.89-691.44 ppm and 0.00-36.71 ppm respectively [11]. According to Drinking Water Quality Standard, there is no maximum acceptable value for both potassium and calcium. This is due to the concentration of potassium and calcium in drinking water is well below to give any human health concern [12]. Whereas the results from a study in Najran showed that the mean concentration of the minerals such as potassium, sodium, magnesium and calcium were higher in groundwater than treated drinking water [13]. Depletion of the minerals content in treated drinking water was proven due to water treatment processes.

In Malaysia, there are two types of common water filter systems used for household, namely point-of-use system and whole house system where it has been reported that around $86 \%$ of residents installed at least one water filter system [14]. Point-ofuse system only treat the water that is for drinking or usage which is installed near the sink. Whole house system treats the water before it accesses into the house which is installed near the water meter or pressurised storage tank [15]. Nanofiltration uses a lower pressure process to remove the large solids or molecules in water. The membrane used in nanofiltration is nanometresized cylindrical pores, which is slightly larger than the membrane used in reverse osmosis. The larger pores membrane allows the water and solutes to pass through easily which in turn causes lower pressure and energy needed, lower solutes removal and higher flow rate. The characteristics of the nanofiltration membrane is suitable to be used for water which has low total dissolved solids [16-18].

Reverse osmosis is a process of water filtration which involves the usage of semipermeable membrane. Reverse osmosis is achieved in which there is an applied pressure on the concentrated side of the membrane. This results in the reverse of natural osmosis which overwhelms the natural osmotic pressure. This process forces the fresh water back through the membrane, or in short can be known as revert the flow of water. The contaminants or salts are remained at the concentrated side of the membrane. The size and electrical charge of ions are the features that impact the removal of ions using reverse osmosis method. Effectiveness of reverse osmosis is based on the raw water characteristics, applied pressure, temperature of raw water and others $[17,18]$. The semi permeable membrane used in reverse osmosis is highly permeable to water which makes it effective in removing metals ions and aqueous salts, for instance sodium, chloride, copper, chromium and lead [19]. Despite the high efficiency of reverse osmosis in ions removal, this technique required high operating pressure and high membrane area per unit volume [20].

Water quality has been main concern of the society as water is needed by human beings to survive. Besides, human beings also obtain some necessary minerals from water instead of food consumption. These minerals are important to maintain the human health and carry out daily functions and processes. Although these minerals act as the key role to several functions in human body, excessive or insufficient of these minerals will affect human's health.

Most of the residents in Kelantan use bore water as their source of water supply due to several limitations. The Kelantan residents complained that their white uniforms were permanently stained after washing by the tap water. The bore water is clearer, gives no permanent stain on white clothes and tastes better than tap water. Residents use tap water as the source of water supply because they did not have access to bore water hence alternatively opted to use filtration system, as normally the supplied tap water contains residues. However, the filtration system would not last long because it was easily clogged by sediments [21].

It is thus necessary to analyse the minerals content in the daily drinking water for both the common sources of daily drinking water among Kelantan residents which are tap water and bore water. However, this current study only preliminarily compares the minerals concentration between the bore water and tap water from the homes of staffs and students of School of Health Sciences (PPSK), Universiti Sains Malaysia (USM). 


\subsection{METHODOLOGY}

\subsection{Subject Recruitment and Questionnaire Distribution}

This was a cross-sectional study design, utilising purposive sampling method and recruited 32 research participants. Staffs and students who consumed tap water and bore water for drinking or cooking were invited to participate into the study via email circulation. Arrangement for home visit were made with those who voluntarily agreed to participate in this study. During the home visit, participants were asked to complete a questionnaire after they have agreed and signed the informed consent form (the study has been granted approval by the USM human ethical board). The questionnaire used in this study was modified from World Health Organisation (WHO) and United Nations Children's Fund (UNICEF) [22]. The questionnaires consisted of four sections, gathering information on sociodemographic, drinking water system, drinking water filter system and drinking water preferences.

\subsection{Water Sampling}

Tap water and bore water were collected from the homes of the staffs and students of the Health Campus, USM. Water samples were collected based on the availability of the types of water samples of either filtered, boiled or raw. The tap water and bore water were required to flow for about 3 to 5 minutes. $500 \mathrm{ml}$ polyethylene bottle was rinsed at least three times with running water before it was filled carefully with the water until full. Each polyethylene bottle was tightly capped and was labelled appropriately with date, time and specific location of sampling. The water samples were transported to the laboratory immediately in ice box. Water samples were preserved by adding $5 \mathrm{ml}$ of concentrated nitric acid immediately once arrived at the laboratory [23] and stored under $4^{\circ} \mathrm{C}$ prior analysis.

\subsection{Standard Preparation of Minerals and Water Sample Analysis}

Water samples were filtered by using Millipore filter paper [24] before being analysed by Flame Atomic Absorption Spectroscopy (FAAS). Stock standard solution and quality control samples for each mineral analysed (magnesium, calcium and potassium) were prepared for calibration following the manufacturer's procedure with concentration of 1000 parts-per-million (ppm). The calibration standard solution and quality control samples were prepared by using molarity standard equation, $\mathrm{M}_{1} \mathrm{~V}_{1}=\mathrm{M}_{2} \mathrm{~V}_{2}$, where $\mathrm{M}$ was the concentration of stock standard solution or quality control samples while $\mathrm{V}$ was the volume of stock standard solution. Calibration standard solutions were prepared in $50 \mathrm{ml}$ volumetric flasks while quality control samples were prepared in $100 \mathrm{ml}$ volumetric flasks. The calibration standard solutions were analyzed first in generating calibration graph curve. Then, both the quality control samples and water samples were analyzed by FAAS. Results were well recorded.

\subsection{Data Analysis}

The Statistical Package for the Social Science (SPSS) version 24 was used for data analysis, at significance level of $\mathrm{p}<0.05$. The results were analysed descriptively and presented in mean and standard deviation (SD). Comparison on the the concentration of minerals between raw and filtered bore water and tap water levels was conducted using Independent Samples T test. The Paired $\mathrm{T}$ Test was utilised to compare the concentration of minerals between raw bore water and tap water after filtration and boiling. Fisher's Exact Test was used to determine the association between perception of research participants on drinking water preferences and water filtration system.

\subsection{RESULTS AND DISCUSSION}

\subsection{Sociodemographic Information of Research Participants}

Research participants' age falls between 27 years old to 65 years old. Majority of the research participants are female (56.8\%, $\mathrm{n}=18)$. Half of the research participants are PPSK staffs such as lecturer $(25.0 \%, \mathrm{n}=8)$, lab assistant $(3.1 \%, \mathrm{n}=1)$, administrative officer or supporting staff $(21.9 \%, \mathrm{n}=7)$. The occupation others than PPSK staffs are students' parents who were housewives, marketing, teachers, retirees, businessman, tutor, office admin assistants and rubber tapper. The research participants had consented 10 bore water and 22 tap water to be collected from their homes. The total number of water samples that were collected 
were 22 raw tap water, 18 filtered tap water, 8 boiled tap water, 10 raw bore water, 10 filtered bore water and one boiled bore water.

\subsection{Information on the Drinking Water System of Research Participants}

Table 1 gathers the information on the drinking water system of the research participants. Fifty percent $(n=5)$ of the research participants who provided bore water reported that they boiled the water before drinking and 54.5\% ( $\mathrm{n}=12)$ consume boiled tap water. All the research participants boiled their water by using kettle. Most of the research participants (bore water: 62.5\%; tap water: $37.5 \%$ ) cleaned their water storage tanks at least once a year. Most of the research participants who provided tap water $(81.8 \%)$ in this study stated that they use polyvinyl chloride (PVC) pipes in their house. Meanwhile, all the research participants who provided bore water also used PVC. Most of the research participants did not boil their filtered water before they drink (bore water: $80.0 \%$; tap water: $72.6 \%$ ). Among research participants who provided bore water, $60.0 \%(\mathrm{n}=6)$ of them knew the type of water filter that they installed in their houses. However, among research participants who provided tap water, $63.6 \%$ $(n=14)$ of them did not know the type of water filter that they installed in their houses (Table 1).

Table 1 Drinking water system of research participants

\begin{tabular}{|c|c|c|c|}
\hline \multirow[t]{2}{*}{ Drinking Water System } & \multicolumn{3}{|c|}{ Frequency $(\%)$} \\
\hline & Bore Water & Tap Water & Total \\
\hline \multicolumn{4}{|c|}{ Boil drinking water before drink } \\
\hline Yes & $5(50.0)$ & $12(54.4)$ & $17(53.1)$ \\
\hline No & $5(50.0)$ & $10(45.5)$ & $15(46.9)$ \\
\hline \multicolumn{4}{|c|}{ Water pass through water storage tank } \\
\hline Yes & $8(80.0)$ & $16(72.7)$ & $24(75.0)$ \\
\hline No & $2(20.0)$ & $6(27.3)$ & $8(25.0)$ \\
\hline \multicolumn{4}{|c|}{ Frequency of cleaning water storage tank } \\
\hline Never & $1(12.5)$ & $3(18.8)$ & $4(16.7)$ \\
\hline At least once a year & $5(62.5)$ & $6(37.5)$ & $11(45.8)$ \\
\hline Once every two years & $1(12.5)$ & $2(12.5)$ & $3(12.5)$ \\
\hline Not sure & $1(12.5)$ & $5(31.2)$ & $6(25.0)$ \\
\hline \multicolumn{4}{|c|}{ Types of water pipes used in house } \\
\hline Galvanized steel & $0(0.0)$ & $4(18.2)$ & $4(12.5)$ \\
\hline Polyvinyl chloride (PVC) & $10(100.0)$ & $18(81.8)$ & $28(87.5)$ \\
\hline \multicolumn{4}{|c|}{ Filter drinking water before drink } \\
\hline Yes & $10(100.0)$ & $18(81.8)$ & $28(87.5)$ \\
\hline No & $0(0.0)$ & $4(18.2)$ & $4(12.5)$ \\
\hline \multicolumn{4}{|c|}{ Boil filtered drinking water before drink } \\
\hline Yes & $2(20.0)$ & $6(27.3)$ & $8(25.0)$ \\
\hline No & $8(80.0)$ & $16(72.7)$ & $24(75.0)$ \\
\hline \multicolumn{4}{|c|}{ Point-of-use water filter system available } \\
\hline Yes & $8(80.0)$ & $16(72.7)$ & $24(75.0)$ \\
\hline No & $2(20.0)$ & $6(27.3)$ & $8(25.0)$ \\
\hline \multicolumn{4}{|c|}{ Whole-house water filter system available } \\
\hline Yes & $6(60.0)$ & $8(36.4)$ & $14(43.8)$ \\
\hline No & $4(40.0)$ & $14(63.6)$ & $18(56.2)$ \\
\hline \multicolumn{4}{|l|}{ Know type of water filter used } \\
\hline Yes & $6(60.0)$ & $8(36.4)$ & $14(43.8)$ \\
\hline No & $4(40.0)$ & $14(63.6)$ & $18(56.2)$ \\
\hline \multicolumn{4}{|l|}{ Types of water filter used } \\
\hline Activated carbon filter & $2(33.3)$ & $4(50.0)$ & $6(42.9)$ \\
\hline Ion exchange units & $0(0.00)$ & $1(12.5)$ & $1(7.1)$ \\
\hline Reverse osmosis & $2(33.3)$ & $2(25.0)$ & $4(28.6)$ \\
\hline Distillation units & $1(16.7)$ & $0(0.0)$ & $1(7.1)$ \\
\hline Nanofiltration & $1(16.7)$ & $1(12.5)$ & $2(14.3)$ \\
\hline
\end{tabular}

\subsection{Drinking Water Preferences}

Research participants were asked to choose or specify the reasons they preferred their types of drinking water. Most of the research participants preferred drinking water with no taste or odour. Four of the research participants specified the reasons that the tap water is more favourable as it was the only source of drinking water available. One of the research participants specified the reasons he/she preferred bore water because chlorine was not added into bore water. However, a study showed that the taste 
sensitivity did not predict the drinking water preferences [25]. However, taste was not the prominent factor as the odours may also affected the preference of drinking water [26].

\subsection{Comparison of Minerals between Bore Water and Tap Water}

There were no significant differences in concentration of minerals between raw bore water and tap water for magnesium $(\mathrm{p}=0.087)$ and potassium $(\mathrm{p}=0.244)$. The mean concentration of calcium in raw tap water (mean: $1.794 \mathrm{mg} / \mathrm{L}, \mathrm{SD}: 1.031 \mathrm{mg} / \mathrm{L})$ is significantly higher than the mean concentration of calcium in raw bore water (mean: $0.801 \mathrm{mg} / \mathrm{L}, \mathrm{SD}: 0.483 \mathrm{mg} / \mathrm{L}$ ), $\mathrm{p}=0.007$ (Table 2). The findings of this study contradicted with the results from the study in Najran showed that the mean concentration of the minerals such as magnesium, calcium, potassium, and sodium were higher in groundwater compared to treated drinking water [13]. Such no statistical significant difference of minerals concentration found between raw bore water and tap water may be due to the sources of tap water samples were from groundwater instead of surface water, in which was the same sources of bore water [3]. However, the mean concentration of calcium in raw bore water was significantly lower than the mean concentration of calcium of raw tap water in this study might be contributed by the process of leaching of the rocks into the groundwater [27]. Concentration of calcium ions in groundwater might be increasing due to the leaching process. High calcium ions intake by human may cause human heart to stop in systole, which eventually may cause respiratory and cardiac failure [28]. Water treatment processes can decrease the minerals content in treated drinking water [13]. Besides, calcium-based fertilisers such as calcium ammonium nitrate may cause the high concentration of calcium in underground due to water infiltration which carry calcium ions from fertilisers [29].

Table 2 Comparison of minerals between bore water and tap water

\begin{tabular}{|c|c|c|c|c|c|c|}
\hline \multirow[t]{2}{*}{ Type of minerals } & \multirow[t]{2}{*}{$\mathbf{n}$} & \multicolumn{3}{|c|}{ Mean (SD) (mg/L) } & \multirow[t]{2}{*}{ t statistic } & \multirow[t]{2}{*}{ p-value } \\
\hline & & Bore Water & $\mathbf{n}$ & Tap Water & & \\
\hline \multicolumn{7}{|l|}{$\underline{\text { Raw }}$} \\
\hline$\overline{\text { Magnesium }}$ & 10 & $0.178(0.090)$ & 22 & $0.294(0.197)$ & 1.768 & 0.087 \\
\hline Calcium & 10 & $0.801(0.483)$ & 22 & $1.794(1.031)$ & 2.886 & $0.007 *$ \\
\hline Potassium & 10 & $0.310(0.117)$ & 22 & $0.361(0.111)$ & 1.188 & 0.244 \\
\hline \multicolumn{7}{|l|}{ Filtered } \\
\hline Magnesium & 10 & $0.173(0.107)$ & 18 & $0.275(0.220)$ & 1.362 & 0.185 \\
\hline Calcium & 10 & 1.103 (1.209) & 18 & $1.652(1.141)$ & 1.195 & 0.243 \\
\hline Potassium & 10 & $0.280(0.101)$ & 18 & $0.337(0.158)$ & 1.028 & 0.313 \\
\hline
\end{tabular}

*Significant different at $\mathrm{p}<0.05$; Statistical test - Independent Samples T Test; SD - Standard Deviation

\subsubsection{Comparison of Minerals Between Filtered And Non-Filtered of Bore Water and Tap Water}

There was no statistical significant difference between mean concentration of minerals between raw and filtered water for both bore water and tap water (Table 3). This finding might be explained by the household water filter system installed was not able to filter out the minerals analysed in this study. In which these minerals (magnesium, calcium, potassium) are essential for human health. In this study, activated carbon was the mostly used water filter system by research participants. Activated carbon was effective for adsorbing natural and synthetic compounds and removing taste and odour in drinking water treatment. Besides, few chemical compounds such as mercury, chromium and arsenic can be removed by granular activated carbon [30] while powdered activated carbon can only adsorb organic chemical, microbial and radiological compounds instead of essential minerals to human health [31]. Other water filtration method such as nanofiltration and reverse osmosis also show high efficiency in removal of fluoride ions in water [32-34]. Additionally, reverse osmosis shows high efficiency in removal of protozoa, bacteria and viruses. However, instead of removal, it may reduce few minerals including the minerals studied in this research [35].

Table 3. Comparison of minerals between filtered and non-filtered bore water and tap water

\begin{tabular}{|c|c|c|c|c|c|}
\hline \multirow[t]{2}{*}{ Type of minerals } & \multicolumn{3}{|c|}{ Mean (SD) (mg/L) } & \multirow[t]{2}{*}{ t statistic } & \multirow[t]{2}{*}{ p-value } \\
\hline & $\mathbf{n}$ & Raw & Filtered & & \\
\hline \multicolumn{6}{|l|}{ Bore Water } \\
\hline Magnesium & 10 & $0.178(0.090)$ & $0.173(0.107)$ & 0.464 & 0.654 \\
\hline Calcium & 10 & $0.801(0.483)$ & 1.103 (1.209) & -1.141 & 0.283 \\
\hline Potassium & 10 & $0.310(0.117)$ & $0.280(0.101)$ & 0.964 & 0.360 \\
\hline \multicolumn{6}{|l|}{ Tap Water } \\
\hline Magnesium & 18 & $0.294(0.197)$ & $0.275(0.220)$ & 1.535 & 0.143 \\
\hline Calcium & 18 & $1.794(1.031)$ & $1.652(1.141)$ & 1.754 & 0.098 \\
\hline Potassium & 18 & $0.361(0.111)$ & $0.337(0.158)$ & 1.119 & 0.279 \\
\hline
\end{tabular}

Statistical test - Paired T Test, SD - Standard Deviation 


\subsubsection{Comparison of Minerals Between Raw and Boiled Tap Water}

There was no significant difference in mean concentration of minerals between raw tap water and boiled tap water ( $\mathrm{p}=0.100$ for magnesium; $p=0.136$ for calcium; $p=0.142$ for potassium) (Table 4). This may due to the boiling points of minerals were higher than the boiling point of water which was caused by the strong ionic bonds [36].

Table 4. Comparison of minerals between raw and boiled tap water

\begin{tabular}{|c|c|c|c|c|c|}
\hline \multirow[t]{2}{*}{ Type of minerals } & \multicolumn{3}{|c|}{ Mean (SD) (mg/L) } & \multirow[t]{2}{*}{ t statistic } & \multirow[t]{2}{*}{ p-value } \\
\hline & $\mathbf{n}$ & Raw Tap Water & Boiled Tap Water & & \\
\hline Magnesium & 8 & $0.324(0.234)$ & $0.219(0.142)$ & 1.893 & 0.100 \\
\hline Calcium & 8 & $1.984(1.181)$ & $1.540(0.894)$ & 1.682 & 0.136 \\
\hline Potassium & 8 & $0.382(0.127)$ & $0.326(0.112)$ & 1.656 & 0.142 \\
\hline
\end{tabular}

\subsection{Comparison of Minerals With Respect To Types of Water Pipes}

There was significant difference in mean concentration of minerals for magnesium $(\mathrm{p}=0.021)$ and calcium $(\mathrm{p}=0.038)$ of raw water samples between galvanised steel pipe and polyvinyl chloride pipe. However no significant difference was found in mean concentration of potassium ( $\mathrm{p}=0.137)$. Furthermore, the difference in mean concentration of minerals of filtered water samples was significant between galvanised steel pipe and polyvinyl chloride pipe for magnesium only $(\mathrm{p}=0.014)$. Table 5 shows that the mean concentration of minerals in raw and filtered water using galvanised steel was higher than the mean concentration of minerals in filtered water using polyvinyl chloride pipe. This may be due to the alloy used in galvanised steel pipes of research participants contained magnesium [37]. Besides, high temperature may cause the calcium and magnesium ions to form scale in the hot water system [38] which available in some water filter system. Corrosion of galvanised steel pipes may cause the builtup of calcium and magnesium on galvanised steel pipes wall in which can be released into the water.

Table 5. Comparison of minerals with respect to types of water pipes

\begin{tabular}{|c|c|c|c|c|c|c|}
\hline \multirow[t]{2}{*}{ Type of minerals } & \multicolumn{4}{|c|}{ Mean (SD) (mg/L) } & \multirow[t]{2}{*}{ t statistic } & \multirow[t]{2}{*}{ p-value } \\
\hline & $\mathbf{n}$ & Galvanised Steel Pipe & $\mathbf{n}$ & Polyvinyl Chloride Pipe & & \\
\hline \multicolumn{7}{|l|}{$\underline{\text { Raw }}$} \\
\hline Magnesium & 4 & $0.445(0.205)$ & 28 & $0.231(0.160)$ & 2.426 & $0.021 *$ \\
\hline Calcium & 4 & $2.449(1.002)$ & 28 & $1.346(0.942)$ & 2.176 & $0.038^{*}$ \\
\hline Potassium & 4 & $0.425(0.048)$ & 28 & $0.334(0.116)$ & 1.527 & 0.137 \\
\hline \multicolumn{7}{|l|}{ Filtered } \\
\hline Magnesium & 4 & $0.450(0.207)$ & 24 & $0.203(0.169)$ & 2.635 & $0.014 *$ \\
\hline Calcium & 4 & $2.501(0.993)$ & 24 & $1.281(1.126)$ & 2.032 & 0.052 \\
\hline Potassium & 4 & $0.433(0.069)$ & 24 & $0.297(0.142)$ & 1.855 & 0.075 \\
\hline \multicolumn{7}{|l|}{ Boiled } \\
\hline$\overline{\text { Magnesium }}$ & 2 & $0.307(0.210)$ & 7 & $0.199(0.115)$ & 1.013 & 0.345 \\
\hline Calcium & 2 & $2.074(1.395)$ & 7 & $1.267(0.739)$ & 1.165 & 0.282 \\
\hline Potassium & 2 & $0.391(0.078)$ & 7 & $0.302(0.109)$ & 1.050 & 0.329 \\
\hline
\end{tabular}

\subsection{CONCLUSION}

Drinking water is essential for human health and well-being. Humans have the rights to access safe and quality drinking water. In this research, concentration of minerals of bore water and tap water were studied. Comparison between concentration of minerals of raw bore water and tap water had no significant difference except for calcium. Similarly, no significant result was observed for the comparison of concentration of minerals in bore water and tap water after filtered and boiling. Concentration of minerals in water samples were found to be higher in galvanised steel pipes compared to PVC types of piping. Low concentration of minerals reported in this study showed that all the water samples were complied to maximum value implemented by Drinking Water Quality Standard. This study can be very useful as the staffs and students can be informed about the mineral contents that available in their drinking water at their homes. 


\section{Acknowledgements}

The authors would like to thank Universiti Sains Malaysia, School of Health Sciences and to all subjects who had participated in this study.

\section{References}

[1] World Health Organization. 2015. Drinking-Water. Available at: http://www.who.int/mediacentre/factsheets/fs391/en/ (Accessed 02 October 2016).

[2] South Australia Environmental Protection Agency. 2016. Bore water (Groundwater). Available at: http://www.epa.sa.gov.au/environmental_info/site_contamination/groundwater (Accessed 24 November 2016).

[3] AKSB (2016) Water treatment process. Available at: http://airkelantan.com.my/makmal-pusat/proses-rawatan-air/ (Accessed 24 November 2016).

[4] Igwemmar, N. C., Kolawole, S. A. and Okunoye, L. K. 2013. Physical and Chemical Assessment of Some Selected Borehole Water in Gwagwalada, Abuja, International Journal of Scientific \& Technology Research. 2(11): 324-328.

[5] World Health Organisation. 2005. Nutrients in Drinking Water. Available at: http://www.who.int/water_sanitation_health/dwq/nutrientsindw.pdf (Accessed 24 November 2016).

[6] Rosborg, I., Nihlgard, B. and Ferrante, M. 2015. Drinking Water Minerals and Mineral Balance. Switzerland: Springer International Publishing

[7] Pohl, H. R., Wheeler, J. S. and Murray, H. E. 2013. Sodium and Potassium in Health and Disease, Metal Ions and Human Diseases. $13: 29-47$.

[8] National Institutes of Health. 2018. Magnesium Fact Sheet for Health Professionals. Available at: https://ods.od.nih.gov/factsheets/MagnesiumHealthProfessional/ (Accessed 19 April 2018).

[9] National Institutes of Health. 2016. Calcium Fact Sheet for Consumers. Available at: https://ods.od.nih.gov/factsheets/Calcium-Consumer/ (Accessed 19 April 2018).

[10] Foster, S., Kemper, K., Tuinhof, A., Koundouri, P., Nanni, M. and Garduno, H. 2006. Natural Goroundwater Quality Hazards, avoiding problems and formulating mitigation strategies. Available at: https:/www.un-igrac.org/sites/default/files/resources/files/GWMATE\%20briefing\%20notes\%20$\% 20$ Quality\%20Hazards.pdf (Accessed 18 May 2017).

[11] Hamzah, Z., Wan Rosdi, W. N., Hj Wood, A. K. and Saat, A. 2014. Determination of Major Ions Concentrations in Kelantan Well Water Using EDXRF and Ion Chromatography, The Malaysian Journal of Analytical Sciences. 18(1): 178-184.

[12] World Health Organisation. 2011. Guidelines for Drinking-water Quality Fourth Edition. Available http://apps.who.int/iris/bitstream/10665/44584/1/978924158151_eng.pdf (Accessed 22 March 2017).

[13] B. B. Law. 2005. The Usage of Domestic Water Filtration Systems in Malaysia, Bachelor Degree thesis, University of Southern Queensland, Australia.

[14] Brima, E. I. 2014. Physicochemical Properties And The Concentration Of Anions, Major And Trace Elements In Groundwater, Treated Drinking Water And Bottled Drinking Water in Najran area, KSA, Applied Water Science. 1-10.

[15] National Sanitation Foundation (2017.) Selecting a Home Water Treatment System. Available at: http://www.nsf.org/consumer-resources/what-is-nsfcertification/water-filters-treatment-certification/selecting-a-water-treatment-system (Accessed 21 May 2017).

[16] Kwai Kut, K. M., Sarswat, A., Srivastava, A., Pittman Jr., C. U. and Mohan, D. 2016. A Review Of Fluoride In African Groundwater And Local Remediation Methods, Groundwater for Sustainable Development. 2: 190-212.

[17] Singh, J., Singh, P. and Singh, A. 2016. Fluoride ions vs removal technologies: A study. Arabian Journal of Chemistry. 9: 815-824.

[18] Jadhav, S. V., Bringas, E., Yadav, G. D., Rathod, V. K., Ortiz, I. and Marathe, K. V. 2015. Arsenic and fluoride contaminated groundwaters: A review of current technologies for contaminants removal, Journal of Environmental Management. 162: 306-325.

[19] Hoornaert. P. 1984. Reverse Osmosis. ScienceDirect [Online]. Available at: https://www.sciencedirect.com/science/article/pii/B9780080311449500066 (Accessed 14 May 2019).

[20] Hoornaert.P. 1984. Reverse Osmosis. ScienceDirect [Online]. Available at: https://www.sciencedirect.com/science/article/pii/B9780080311449500108 (Accessed 14 May 2019).

[21] Ishar, M. Z. 2009. Drink 'Air Boring' Anybody? Bernama.com, 10 March [Online]. Available at: http://bernama.com.my/bernama/v3/printable.php?id=395039 (Accessed 24 November 2016).

[22] World Health Organization and United Nations Children's Fund. 2006. Core Questions on Drinking-Water and Sanitation for Household Surveys. Geneva: WHO Press. 
[23] Sharma, P., Dubey, A. and Chatterjee, S. K. 2013. Determination of heavy metals in surface and ground water in an around (Agrang Block) Raipur District, Chhattisgarh, India, International Journal of Scientific \& Engineering Research. 4(9): 722-724.

[24] Lakshmi, D. V., Rao, J. K., Ramprakash, T. and Reddy, A. P. K. 2016. Agricultural Puposes in Ramannapet Mandal of Nalgonda District, Telangana, India, Journal of Pharmaceutical, Chemical and Biological Sciences. 4(2): 169-175.

[25] Harmon, D., Gauvain, M., Reisz, Z., Arthur, I. and Story, S. D. 2018. Preference for tap, bottled, and recycled water: Relations to PTC taste sensitivity and personality. Appetite. 121: 119-128.

[26] Spence. 2016. Oral Referral: On The Mislocalization Of Odours To The Mouth/ Food Quality And Preference. 50: 117-128.

[27] Krishnan, R. R., Dharmaraj, K. And Kumari, B. D. R. 2007. A Comparative Study On The Physicochemical And Bacterial Analysis Of Drinking, Borewell And Sewage Water In Three Different Places of Sivakasi. Journal of Environmental Biology. 28(1): 105-108.

[28] Soetan, K. O., Olaiya, C. O. and Oyewole, O. E. 2010. The Importance Of Mineral Elements For Humans, Domestic Animals And Plants: A Review. African Journal of Food Science. 4(5): 200-222.

[29] Christine, A. A., Kibet, J. K., Kiprop, A. K. and Were, M. L. 2018. The Assessment Of Bore-Hole Water Quality of Kakamega County, Kenya. Applied Water Science. 46-53.

[30] United States Environmental Protection Agency. 2018a. Granular Activated Carbon. Available at: https://iaspub.epa.gov/tdb/pages/treatment/treatmentOverview.do?treatmentProcessId=2074826383 (Accessed 15 April 2018).

[31] United States Environmental Protection Agency .2018b. Powdered Activated Carbon. Available at: https://iaspub.epa.gov/tdb/pages/treatment/treatmentOverview.do?treatmentProcessId=2109700949 (Accessed 15 April 2018).

[32] Jadhav, S. V., Marathe, K. V. and Rathod, V. K. 2016. A Pilot Scale Concurrent Removal Of Fluoride, Arsenic, Sulfate And Nitrate By Using Nanofiltration: Competing Ion Interaction And Modelling Approach. Journal of Water Process Engineering. 13: 153-167.

[33] Shen, J., Richards, B. S. and Schafer, A. I. 2016. Renewable Energy Powered Membrane Technology: Case Study Of St. Dorcas Borehole In Tanzania Demonstrating Fluoride Removal Via Nanofiltration/Reverse Osmosis, Separation and Purification Technology. 170: 445-452.

[34] Stalter, D., O’Malley, E., Gunten, U. V. and Escher, B. I. 2016. Point-of-Use Water Filters Can Effectively Remove Disinfection By-Products And Toxicity From Chlorinated And Chloraminated Tap Water, Environmental Science: Water Research \& Technology. 2: 875-883.

[35] Centers for Disease Control and Prevention. 2008. Drinking Water Treatment Technologies for Household Use. Available at: https://www.cdc.gov/healthywater/pdf/drinking/Household_Water_Treatment.pdf (Accessed 08 May 2019).

[36] Gallagher, R. and Ingram, P. 2006. Chemistry for Higher Tier (New Coordinated Science). New York: Oxford University Press.

[37] Keppert, T. A., Luckeneder, G., Stellnberger, K.-H, Commenda, C., Mori, G. and Antrekowitsch, H. 2014. The Effect Of Magnesium On The Corrosion Of Hot-Dip Galvanized Steel In Chloride Containing Environments. Materials and Corrosion. 65(9): 871-880.

[38] Shammas, N. K. and Wang, L. K. 2015. Water Engineering: Hydraulics, Distribution and Treatment. Google Books [Online]. Available at: https://books.google.com.my/books?id=v_-mCAAAQBAJ\&pg=PA646\&lpg=PA646\&dq\#v=onepage\&q\&f=false (Accessed 23 April 2018). 